\title{
DISEMINASI INFORMASI PEDULI LINGKUNGAN PADA MASYARAKAT DESA PALEDAH KABUPATEN PANGANDARAN
}

\author{
Neneng Komariah, Pawit M. Yusup, Encang Saepudin, dan Saleha Rodiah \\ Prodi Ilmu Perpustakaan, Fakultas Ilmu Komunikasi, Universitas Padjadjaran \\ E-mail: neneng.komariah@unpad.ac.id
}

\begin{abstract}
ABSTRAK. Daerah perkebunan dan perhutanan bisa menjadi tujuan wisata baru yang menawarkan keindahan alam dan pendidikan. Selain itu, dengan berkembangnya agrowisata di satu daerah tujuan wisata akan memberikan manfaat untuk peningkatan pendapatan masyarakat dan pemerintah. Agar potensi wisata alam dapat terus dipertahankan dan diwariskan pada generasi di masa mendatang, diperlukan usaha dan kerjasama masyarakat sekitar untuk terus melestarikan alam serta kekhasannya. Salah satunya dengan diseminasi informasi peduli lingkungan pada masyarakat Desa Paledah Kabupaten Pangandaran. Metode pelaksanaan PPM ini dilakukan dengan focus group discussion (FGD) yang dilaksanakan oleh aparatur desa, pengembang desa agrowisata, para kader PKK, guru PAUD dan tim pelaksana PPM. Dari FGD tersebut dihasilkan upaya diseminasi berupa buku panduan dan infografis mengenai informasi peduli lingkungan. Upaya ini dilakukan agar masyarakat Desa Paledah memiliki sikap peduli lingkungan yang dapat terlihat dari perilaku sehari-hari dengan selalu menjaga kebersihan, aktif kerja bakti, hemat air dan energi.
\end{abstract}

Kata kunci: agrowisata; informasi peduli lingkungan; focus group discussion; buku panduan; diseminasi

\begin{abstract}
Plantation and forestry areas can become new tourist destinations that offer natural beauty and education. In addition, the development of agrotourism in a tourist destination will provide benefits for increasing the income of the community and government. So that the potential for natural tourism can continue to be preserved and bequeathed to future generations, it takes the effort and cooperation of the surrounding community to continue to preserve nature and its uniqueness. One of them is by disseminating information on environmental care to the people of Paledah Village, Pangandaran Regency. The PPM implementation method was carried out with a focus group discussion (FGD) conducted by village officials, agro-tourism village developers, PKK cadres, PAUD teachers and PPM implementation team. The FGD resulted in dissemination efforts in the form of guidebooks and infographics about information about the environment. This effort is carried out so that the Paledah Village community has an attitude of caring about the environment that can be seen from daily behavior by always maintaining cleanliness, active community service, saving water and energy.
\end{abstract}

Key words: agro-tourism; environmental care information; focus group discussion; guidebooks; dissemination

\section{PENDAHULUAN}

Desa Paledah merupakan salah satu daerah yang dikenal sebagai kampung wisata argo. Istilah wiasata agro atau agrowisata didefinisikan oleh Sajur (2001) sebagai rangkaian aktivitas perjalanan wisata yang memanfaatkan suatu daerah atau sektor pertanian mulai dari awal produksi hingga diperoleh produk pertanian dalam berbagai sistem dengan tujuan memperluas pengetahuan, pemahaman, pengalaman, dan rekreasi di bidang pertanian. Objek wisata yang ditonjolkan oleh Desa Paledah adalah pemandangan alam kawasan pertaniannya maupun kekhasan dan keanekaragaman aktivitas produksi dan teknologi pertanian serta budaya masyarakat pertaniannya. Kegiatan agrowisata bertujuan untuk memperluas wawasan, pengalaman rekreasi, dan hubungan usaha di bidang pertanian yang meliputi tanaman pangan, holtikultura, perkebunan, perikanan, dan peternakan. Daerah perkebunan dan perhutanan bisa menjadi tujuan wisata baru yang menawarkan keindahan alam dan pendidikan. Seperti agrowisata di daerah Cibuntu yang memiliki kawasan pesawah dan perkebunan yang indah. Daya tarik dari persawahan ini adalah pertama sumber air yang selalu tersedia, bahkan berlebihan pada musim penghujan. Selain itu lahan sawah berdampingan dengan tanaman ubi jalar (penduduk memberi nama ubi jalar Manohara karena bentuk ubi yang bulat dan montok).
Pengolahan pasca panen ubi Manohara ini sedikit demi sedikit akan dikembangkan baik rasa, bentuk dan kemasan agar dapat bernilai ekonomis, dan direncanakan sebagai oleh-oleh bagi para wisatawan yang mengunjungi Desa Cibuntu (Bafdal, Balia, Dwiratna, \& Amaru, 2014).

Selain itu, dengan berkembangnya agrowisata di satu daerah tujuan wisata akan memberikan manfaat untuk peningkatan pendapatan masyarakat dan pemerintah. Dengan kata lain, fungsi pariwisata dapat dilakukan dengan fungsi budi daya pertanian, pemukiman pedesaan, dan fungsi konservasi. Potensi wisata alam ini harus tetap dipertahankan hingga kelak dapat diwariskan pada generasi di masa mendatang. Untuk itu diperlukan upaya masyarakat sekitar untuk terus melestarikan alam maupun kekhasannya dengan baik. Diperlukan kerjasama semua pihak agar perkembangan dan kelangsungan desa agrowisata ini sesuai dengan yang diharapkan bersama.

Saat ini banyak anak-anak yang menghabiskan waktunya serta melakukan beragam kegiatan pokoknya yang jauh dari kontak langsung dengan alam, begitupula anak-anak di Kecamatan Padaherang Kabupaten Pangandaran. Hiburan pun cenderung dilakukan di rumah (seperti nonton televisi, video game, interaksi dan berkomunikasi melalui media sosial).

Menurut Disinger dan Roth dalam (Zaini, 2002), akibat dari kegiatan tersebut, banyak anak kecil beresiko tidak dapat mengembangkan sikap dan perasaan positif 
terhadap lingkungan atau mencapai tingkat kompetensi yang sehat pada lingkungan. Anak-anak belajar mengenai interaksi yang sehat dengan lingkungan melalui orangorang terdekatnya, yaitu orangtuanya dan selanjutnya melalui guru dan teman-temannya di sekolah. Sebaiknya sejak dini mereka belajar berinteraksi positif dengan lingkungan, agar semakin bertumbuh pengembangan kesehatan anak dan melalui alam mereka dapat menemukan sumber-sumber "kepekaan manusia" (Wilson, 2000). Salah satu upaya yang dapat dilakukan adalah melalui pendidikan literasi lingkungan.

Literasi lingkungan merupakan kemampuan dari setiap individu dalam memahami dan menafsirkan kondisi lingkungan, sehingga dapat memutuskan tindakan yang tepat dalam mempertahankan, memulihkan serta meningkatkan kondisi suatu lingkungan (Holdaway, 1979). Selain itu literasi lingkungan merupakan kemampuan dari setiap individu terkait dengan pengetahuan, keterampilan dalam berpikir, sikap dan bagaimana memberikan perilaku terhadap lingkungan (Prasetiyo, 2017). Melalui literasi lingkungan individu maupun kelompok dapat mengantisipasi dan mengatasi permasalahan lingkungan.

Dewasa ini, masyarakat memiliki kecenderungan menjauh dari sikap peduli lingkungan, seperti buang sampah sembarangan, tidak menjaga kebersihan, menggunakan sampah yang tidak dapat didaur ulang, menggunakan air dan energi listrik secara berlebihan, banyak yang memilih menggunakan kendaraan bermotor daripada berjalan kaki, dan lain-lain. Berdasarkan hal tersebut, maka diperlukan upaya untuk menyebarluaskan pendidikan literasi lingkungan khususnya dalam membangun sikap pedulu lingkungan pada masyarakat Desa Paledah.

\section{METODE}

Metode pelaksanaan kegiatan pengabdian pada masyarakat terdiri dari beberapa tahapan, antara lain:

1) Persiapan. Tahap persiapan merupakan tahap awal sebelum pelaksanaan PPM. Dalam tahap ini ada beberapa kegiatan yang dilakukan yakni: (a) Koordinasi internal, dilakukan oleh Tim untuk merencanakan pelaksanaan secara konseptual, operasional, serta job description. (b) Survey lokasi dan perijinan ke instansi terkait. (c) Pembuatan instrumen PPM, seperti materi FGD, presensi, angket pre-test dan posttest. (d) Persiapan konsumsi, publikasi, lokasi, serta dokumentasi. (e) Mempersiapkan materi FGD.

2) Pelaksanaan Diskusi Kelompok Terpusat (FGD). Pada tahap ini dilakukan kegiatan diskusi kelompok terpusat dengan narasumber, ketua dan anggota tim agro wisata untuk membuat formulasi panduan bagi pengembang pendidikan literasi lingkungan yang tepat bagi pendidikan literasi pemeliharaan lingkungan. Dalam pelaksanaannya Tim PPM dosen melibatkan mahasiswa untuk membantu hal-hal teknis.
3) Pembahasan Draft Panduan. Pelaksanaan Pembahasan draf panduan ini mencakup beberapa hal berikut, yaitu: (a) Kegiatan menjawab secara tertulis draft panduan. Sebelum dilakukan pembahasan draf panduan, peserta mengisi daftar pertanyaan untuk mengetahui harapan kader PKK dan guru-guru PAUD terkait panduan bagi pengembang pendidikan literasi lingkungan. (b) Pembahasan draft panduan. Peserta dibimbing dalam memperjelas konsep panduan bagi pengembangan pendidikan literasi pemeliharaan lingkungan. Kegiatan pembahasan ini dilakukan dalam satu hari tatap muka mulai dari pukul 13.00 sampai dengan pukul 15.30.

4) Monitoring dan evaluasi. Dari kegiatan FGD dan pembahasan draf panduan yang telah dilakukan, selanjutnya dipantau dengan kegiatan monitoring dan evaluasi hasil kegiatan PPM, sebagai umpan balik pelaksanaan PPM.

\section{HASIL DAN PEMBAHASAN}

Upaya diseminasi informasi peduli lingkungan di Desa Paledah menggunakan berbagai metode yakni FGD, Pembuatan buku panduan dan pembuatan infografis mengenai informasi kesehatan lingkungan.

1. Diskusi Kelompok Terpusat (FGD)

Hasil observasi kawasan Desa Paledah diperlukan adanya penguatan pendidikan literasi pemeliharaan lingkungan sejak dini, agar kawasan desa agrowisata tetap terjaga keindahan dan kelestariannya. Untuk itu perlu dilakukan diskusi kelompok terpusat agar dapat membuat solusi atas masalah lingkungan yang terjadi di desa tersebut. Diskusi tersebut mengundang beberapa stakeholder yakni, Kepala Desa Paledah, aparat pemerintahan desa, pengurus pengembangan desa agrowisata dan perwakilan khalayak sasaran(kaderPKK dan guruPAUD). Perubahan lingkungan setiap tahun pasti akan terjadi baik dalam konteks lokal maupun global, sehingga tujuan ditingkatkannya literasi lingkungan adalah untuk mempersiapkan manusia yang memahami dan dapat mengatasi permasalahan lingkungan, sehingga dapat dipersiapkan agen-agen pembaharu lingkungan yang memiliki sikap dan tindakan yang positif terhadap lingkungan. Dalam Yanti, Yustina, \& Rosmaini (2013) disebutkan peningkatan literasi lingkungan kepada siswa dapat dilakukan dengan berbagai cara dalam proses pembelajaran. Beberapa penelitian terkait literasi lingkungan diantaranya penelitian tentang pengembangan instrumen literasi lingkungan untuk mengukur pengetahuan, sikap, perilaku dan keterampilan. Hasil penelitian menunjukkan bahwa adanya korelasi antara sikap dan perilaku paling kuat, sedangkan antara pengetahuan dan perilaku paling lemah; ditemukan gender, latar belakang sekolah orang tua, dan sumber informasi siswa tentang lingkungan mempengaruhi literasi lingkungan.

Dalam diskusi tersebut, ditentukan garis besar komponen pengembangan pendidikan literasi pemeliharaan lingkungan, antara lain: 
a) Mulai dengan pengalaman-pengalaman sederhana Di sini para peserta PPM mulai menceritakan dan mendiskusikan pengalaman-pengalaman sederhana terkait pemeliharaan lingkungan, misalnya menjaga kebersihan rumah, membuang sampah pada tempatnya, tidak menggunakan plastik atau sterofoam, serta penghematan terhadap air dan energi listrik.

b) Sering memberikan pengalaman positif di luar rumah. Dalam hal ini para kader dan guru selalu berusaha untuk konsisten dalam menjaga lingkungan, tidak hanya lingkungan di rumah saja namun juga saat mereka pergi keluar rumah. Misalnya membiasakan jalan kaki jika sekedar menuju tempat yang dekat, melakukan kerja bakti, dan mengajak orang-orang sekitar untuk peduli terhadap lingkungan.

c) Fokuskan pada pengalaman dibanding pengajaran. Para kader PKK dan para guru dalam menumbuhkan sikap peduli lingkungan dimulai dari perilaku seharihari agar dapat dilihat dan dijadikan contoh bagi keluarga terdekat ataupun masyarakat sekitar. Tidak perlu menggunakan ceramah panjang lebar, cukup dengan membuktikan diri melalui perilaku yang mencerminkan sikap peduli lingkungan.

d) Tunjukkan minat pribadi terhadap lingkungan dan kesenangan berada di alam nyata. Memberi contoh kepada keluarga khususnya ataupun masyarakat sekitar mengenai penanaman tanaman obat, tanaman bunga, ataupun pohon buah-buahan di sekitar rumah mereka.

e) Guru sebagai model dalam memelihara lingkungan. Peran guru di sini sangat penting baik ketika berada di sekolah ataupun di rumah. Guru merupakan panutan dan contoh yang baik dalam memelihara lingkungan.

\section{Pembuatan Buku Panduan dan Infografis}

Kegiatan ini dilakukan untuk mendapatkan hasil terbaik dari panduan penddikan literasi pemeliharaan lingkungan untuk anak. Pembahasan draf panduan ini dilakukan bersama dengan sasaran audiens, yaitu para kader PKK dan Guru-guru PAUD.

Pembahasan draf panduan dilakukan dalam satu hari tatap muka mulai dari pukul 13.00 sampai dengan pukul 15.30. Alasan pemilihan waktu agar tidak mengganggu aktivitas utama guru-guru PAUD. Kegiatan penyuluhan diikuti oleh 30 orang peserta yang terdiri dari perwakilan kader aktif PKK tingkat desa dan guru-guru Pendidikan Usia dini (PAUD) di Desa Paledah Kecamatan Padaherang Kabupaten Pangandaran.

Panduan ini berisi pengetahuan mengenai teknik dan keterampilan dalam mengembangkan pendidikan literasi pemeliharaan lingkungan untuk anak bagi guruguru PAUD dan para kader PKK. Upaya sederhana namun mendasar bagi kelangsungan kawasan desa agrowisata yang dapat ditanamkan pada anak-anak sejak dini untuk pelestariannya. Selain itu menambah kesadaran dan percaya diri bahwa menerapkan pendidikan literasi lingkungan ini mempunyai peran penting dalam kegiatan pembangunan dan hal tersebut berarti mereka mampu berperan serta aktif membentuk agen perubahan sejak dini untuk kelestarian lingkungan di masa mendatang.

Peserta sangat antusias mengikuti pembahasan draf panduan dan memberi masukan untuk kelengkapan panduan tentang pendidikan literasi pemeliharaan lingkungan ini berdasarkan situasi dan kondisi lapangan yang mereka hadapi. Panduan pendidikan literasi pemeliharaan lingkungan hasil diskusi ini sebagian besar sudah mereka implementasikan langsung di ranah kerja masing-masing peserta.

Setelah dilakukan pembahasan draf panduan pendidikan literasi pemeliharaan lingkungan, selanjutnya tim Pengabdian pada Masyarakat melaksanakan kegiatan monitoring dan evaluasi (Monev) untuk mengevaluasi kegiatan PPM yang telah dilakukan. Dalam kegiatan tersebut pula diserahkan hasil kegiatan PPM berupa buku panduan dan infografis pendidikan literasi pemeliharaan lingkungan. Panduan pemeliharaan lingkungan untuk sasaran audiens PPM (Guru-guru PAUD dan kader PKK) agar dapat menerapkan panduan dan infografis tersebut pada anak didiknya. Sedangkan infografis pendidikan literasi pemeliharaan lingkungan untuk anak yang dapat dipasang di sekolah PAUD dan lokasi pos pelayanan terpadu (Posyandu).

Selanjutnya formulasi bentuk pendidikan literasi pemeliharaan lingkungan; metode pendidikan, media serta pendekatan yang dilakukan diupayakan melalui publikasi jurnal pengabdian pada masyarakat. dari kegiatan pkm ini telah ditulis 1 artikel dan dikirimkan pada Jurnal Dharmakarya Universitas Padjadjaran. artikel tersebut berjudul: "Diseminasi Informasi Peduli Lingkungan pada Masyarakat Desa Paledah Kabupaten Pangandaran”. ditulis oleh: Neneng Komariah, Pawit M. Yusup, Encang Saepudin dan Saleha Rodiah.

\section{SIMPULAN}

Telah dilakukan pembuatan panduan pendidikan literasi pemeliharaan lingkungan yang dapat diaplikasikan Guruguru PAUD dan kader PKK untuk anak didiknya dan infografis pendidikan literasi pemeliharaan lingkungan untuk anak yang dapat dipasang di sekolah PAUD dan lokasi pos pelayanan terpadu (Posyandu). Media komunikasi tersebut dibuat sebagai sarana diseminasi informasi peduli lingkungan untuk masyarakat Desa Paledah.

\section{UCAPAN TERIMAKASIH}

Terimakasih kepada Kepala Desa Paledah yang telah memberikan ijin dan memfasilitasi kegiatan pengabdian pada masyarakat prodi Ilmu Perpustakaan Unpad sehingga kegiatan ini dapat terlaksana dengan baik. Selain itu tidak lupa kami ucapkan kepada para kader PKK dan guru PAUD di Desa Paledah atas partispasinya secara aktif dalam kegiatan PPM ini. 


\section{DAFTAR PUSTAKA}

Bafdal, N., Balia, R.L., Dwiratna, S. \& Amaru, K. (2014). Penyusunan Peta Potensi Desa Agrowisata Berbasis Masyarakt Di Desa Cibuntu. Dharmakarya, 3, (2), 81-87.

Holdaway, E.A. (1979). The foundations of literacy. Sydney: Ashton Scholastic.

Prasetiyo. (2017). Pembelajaran Matapelajaran Biologi Materi Lingkungan Di Sekolah Mengengah Atas Dan Daya Dukungnya Terhadap Literasi Lingkungan Siswa. Florea, 4, (2), 55-58.

Sajur, N. (2001). Pengembangan kawasan wisata agro (Agrotourism). Buletin Tanaman Dan Lanskap Indonesia, 4, (2), 20-23.
Wilson, T.D. (2000). Human Information Behavior. Information Science Research, 3, (2), 49-56.

Yanti, F., Yustina, \& Rosmaini. (2013). Analisis Literasi Lingkungan Hidup Mahasiswa Pada Mata Kuliah Ilmu Pengetahuan Lingkungan Program Studi Pendidikan Biologi Fkip Universitas Riau Tahun Akademis 2011/2012. Universitas Riau. Retrieved from https://repository.unri.ac.id/ handle/123456789/1574

Zaini, M. (2002). Pendidikan Lingkungan bagi Anak untuk Mewujudkan Masyarakat yang Memiliki Literasi Lingkungan. Fikrah, 1, (1), 1-7. 